\title{
A AUTORREPRESSÃO DO DESEJO EM MARTA, DE MEDEIROS E ALBUQUERQUE: UMA ANÁLISE DELEUZIANA-GUATTARIANA DO INCESTO
}

\author{
Franco Baptista Sandanello* \\ Université Sorbonne Nouvelle - Paris III \\ Paris, FR. \\ Vanessa de Oliveira Temporal ${ }^{\star \star}$ \\ Universidade Federal de São Carlos \\ São Carlos, SP, BR.
}

\section{Resumo}

A partir de reflexões presentes na obra O Anti-Édipo, de Gilles Deleuze e Félix Guattari (2011), referentes à perenidade do complexo de Édipo na sociedade capitalista contemporânea e, especialmente, na literatura, enquanto signo da falta e da pulsão incestuosa, discute-se no presente artigo a autorrepressão do desejo no romance Marta (2013), de Medeiros e Albuquerque, exemplo privilegiado e único de um romance brasileiro inteiramente construído acerca da questão do incesto. Neste sentido, aponta-se para a íntima conexão existente entre a literatura e o pensamento deleuziano-guattariano, e para a reflexão simultânea que pode haver entre ambos.

Palavras-chave: Incesto; Deleuze e Guattari; literatura brasileira; Medeiros e Albuquerque.

\section{THE SELF-REPRESSION OF DESIRE IN MARTA, BY MEDEIROS E ALBUQUERQUE: A DELEUZIAN-GUATTARIAN ANALYSIS OF INCEST}

\begin{abstract}
From a number of reflections present in O Anti-Édipo, by Gilles Deleuze and Félix Guattari (2011), regarding the perpetuity of the Oedipus complex in capitalist contemporary society, and, specially, in literature, as the sign of absence and incestuous drive, the present article discusses the self-repression of desire in the novel Marta (2013), by Medeiros e Albuquerque, a unique and privileged example of a Brazilian novel entirely crafted around the theme of incest. In this regard, this article points out the intimate connection between literature and deleuzianguattarian thought, and the simultaneous reflection that can exist between them.
\end{abstract}

Keywords: Incest; Deleuze and Guattari; Brazilian literature; Medeiros e Albuquerque.

\footnotetext{
Franco Baptista Sandanello está atualmente pesquisando a obra de Domício da Gama em um estágio pós-doutoral na Université Sorbonne Nouvelle - Paris III, enquanto requisito parcial para suas pesquisas na Universidade Estadual Paulista. Os tópicos com que trabalha versam sobre o oitocentismo brasileiro e as primeiras décadas do século XX. E-mail: fbsandanello@gmail.com.

${ }^{* *}$ Vanessa de Oliveira Temporal realiza atualmente seu doutorado em Filosofia na Universidade Federal de São Carlos em regime de cotutela com a Université Jean Moulin - Lyon III, com ênfase na História da Filosofia Contemporânea. Seus interesses concentram-se na origem da Fenomenologia, sobretudo em torno do conceito de intencionalidade e sua articulação com a linguagem. E-mail: vanessatemporal@yahoo.com.br.
} 


\section{Introdução}

Há um momento na História em que a forma do desejo aparece necessariamente sob a forma de Édipo. A psicanálise tem nele sua metafísica inconfessa: a repressão desfigura o "verdadeiro" desejo, concebe-o em termos de falta e resume-se à pulsão incestuosa; todas as esferas sociais, mesmo a narração literária, estão em termos de Édipo. Mais do que compreender os mecanismos de dominação política, é necessária uma explicação para a autorrepressão do desejo; é preciso denunciar os usos ilegítimos da síntese do inconsciente, que parte de um diagnóstico das formas de repressão na relação entre capitalismo e familismo.

Estes são alguns dos dizeres de Gilles Deleuze e Félix Guattari em $O$ Anti-Édipo, obra que coaduna com seu tempo, 1972 (ou, antes, com o fracasso de maio de 68). A leitura desta obra traz uma pergunta latente: como dar corpo a forças revolucionárias capazes de fazer a produção social passar ao serviço da produção desejante? A resposta dos autores vem três anos depois, em 1975, com Kafka: por uma literatura menor. Enquanto "máquina de guerra", a literatura menor deve promover uma verdadeira experimentação política e está em oposição à literatura de forma edipiana, que se iguala a um objeto de consumo em conformidade com a ordem estabelecida. "Édipo é literário antes de ser psicanalítico” (DELEUZE; GUATTARI, 2011, p. 181).

Este artigo parte do caráter ambíguo da literatura presente em $O$ Anti-Édipo, ora mercadoria, ora máquina política, e identifica uma polarização entre os conceitos de significante e expressão (domínio da metáfora: passagem do sentido próprio ao figurado) com os de signo e produção (domínio da metamorfose: produção de sentido por meio da destruição do significante), a fim de, nesta mesma via, analisar a polarização do incesto no romance Marta, de Medeiros e Albuquerque (2013), ora como forma pura de amor, ora como imoral. Através de uma análise das considerações sobre a literatura e o incesto em $O$ Anti-Édipo, sustenta-se que, assim como a literatura angloamericana e sua aparente alienação pequeno-burguesa, supostamente ausente de crítica social, a obra de Medeiros e Albuquerque também traz uma representação social eficaz do mundo, estando longe de ser uma simples análise de um caso excêntrico em meio à belle époque carioca.

\section{A edipianização da subjetividade e o incesto em O Anti-Édipo}

Em O Anti-Édipo, referindo-se particularmente à literatura angloamericana ao final do segundo capítulo, Deleuze e Guattari (2011, p. 179) dizem que apesar de nela haver uma forte resistência ao capitalismo, ela volta a fechar-se em um impasse neurótico em que persiste o registro da edipianização. Isto leva a inferir que nesta literatura há uma oscilação entre a transposição de um limite atual e da reincorporação, sobretudo inconsciente, nos padrões do consumo e espetacularização da vida, através da perversão, da droga, do álcool etc. A ênfase está na falha desta literatura angloamericana em romper com a ideologia dominante. Porém, nota-se a especificidade da proposta de Deleuze e Guattari (2011, p. 179-180) à análise literária:

\begin{abstract}
Mas através dos impasses e triângulos [da literatura angloamericana] corre um fluxo esquizofrênico, irresistível, esperma, rio, esgoto, blenorragia ou vaga de palavras que não se deixam codificar, libido demasiado fluida e demasiado viscosa: uma violência à sintaxe, uma destruição concertada do significante, o não senso erigido em fluxo, plurivocidade que volta a adentrar todas as relações.
\end{abstract}

A "falha" da literatura angloamericana dá-se a partir do estabelecimento de uma correlação apressada de elementos sociais da obra literária à realidade social. Esta correlação baseia-se em uma incompreensão do funcionamento do desejo, que faz observar na literatura "uma violência à sintaxe, uma destruição concertada do significante", uma coerência interna do aparente "não senso". Tudo isto leva à observação de outro registro da análise literária angloamericana: a destruição/superação do significante do consumo e do espetáculo.

Logo em seguida à citação acima, há uma transição do âmbito particular para o universal quando os autores passam a considerar a literatura em geral. A relação que a literatura mantém com o social não se dá de maneira 
direta. É apenas a obra, enquanto campo de produção, que tem a potência de "sempre despertar um jovem adormecido" (idem, p.180). Esta potência está ligada, sobretudo, àquele "momento em que o signo emitido atravessa esta 'forma de conteúdo' que tentava mantê-la na ordem do significante" (idem, p.180, grifo nosso). A polarização signo/significante traduz em âmbito formal a especificidade da análise social de Deleuze e Guattari e significa um transbordamento do signo, enquanto produtor de desejo, em relação ao significante, que se limita a uma escrita discursiva, linearizada, estabelecidamente entrelaçada ao poder dominante e reprodutora de seus mecanismos de dominação. É o que defende Engels ao discorrer sobre Balzac (idem, 2011, p. 180), que para ele seria um grande escritor na medida em que sua narrativa não pode "deixar de traçar e fazer correr fluxos que arrombam o significante católico e despótico de sua obra, e que alimentam necessariamente uma máquina revolucionária no horizonte". Neste sentido, mesmo que sua obra incorpore figuras e elementos do clero e da realeza sem endereçar diretamente a eles uma crítica, a narrativa de Balzac, sob a figura de um fluxo, comporta um processo de quebra de significante. Em literatura, não é preciso dizer, pois, que um rei é corrupto, bastando mencionar que seus olhos se desviam de alguém desafortunado e sua cabeça se volta unicamente para outro, mais abastado. Os termos "olhos" e "cabeça" adquirem, assim, um caráter de signo, que de maneira transcursiva (i.e., em oposição à discursiva) rompem com o ideal de uma natureza superior da nobreza, desviando-se da lógica própria ao significante despótico.

Em Deleuze e Guattari (2011), a potência revolucionária latente na literatura recebe diferentes denominações: "estilo", "ausência de estilo", "assintaxia", "agramaticalidade", todas elas buscando ressaltar uma profundidade dentro da linguagem que não obedeça ao discurso em sua linearidade narrativa, mas que traga uma verticalidade própria ao desejo. Nas palavras dos autores, esta potência é o

momento em que a linguagem já não mais se define pelo que ela diz, e ainda menos pelo que a torna significante, mas por aquilo que a faz correr, fluir, romper-se - o desejo. Porque a literatura é exatamente como a esquizofrenia: um processo e não uma meta, uma produção e não uma expressão. (idem, p. 180, grifo nosso).

Se anteriormente foram apresentados os termos signo/significante como aspectos formais da análise de Deleuze e Guattari (2011), expressão/produção assumem agora o papel de correlatos dos primeiros, marcando duas formas distintas de registro para a significação. A expressão implica que o sentido tem sua origem fora do sujeito. A base deste tipo de significação é social, porém em sentido negativo; fora do sujeito significa uma anulação deste e é sinônimo de despotismo. Já a produção implica que o sentido é criado diretamente pelo sujeito, inclusive nos termos em que é colocado. Vale conferir destaque ao fato desta segunda acepção de sentido não deixar de ser também social:

Desde o começo deste estudo, sustentamos,
ao mesmo tempo, que a produção social e a
produção desejante são uma só coisa, mas que
diferem em regime, de modo que uma forma
social de produção exerce uma repressão essen-
cial sobre a produção desejante, e também que
a produção desejante (um "verdadeiro" desejo)
pode potencialmente explodir a forma social.
(idem, p. 159, grifo nosso)

O desejo tem, na sua essência, uma relação com o social, de modo a influenciar na produção social, assim como esta última também produz o desejo. Vale notar, a partir da citação acima, que o enfoque dado pelos autores em $O$ Anti-Édipo volta-se para o aspecto da repressão que a forma social de produção exerce sobre a produção desejante e para o poder revolucionário do desejo. Este último é apresentado, devido à sua natureza, como sempre fazendo frente às estruturas de exploração, de sujeição e de hierarquia. Enquanto a sociedade comportar algum destes elementos, o desejo será revolucionário. Vale notar que a libertação do desejo de uma forma pré-determinada é também denominada "corpo sem órgãos" (CsO), conceito inspirado em Antonin Artaud, e que representa um repúdio a toda forma de organismo ou organização, sendo "o socius desterritorializado, deserto onde escorrem os fluxos descodificados do desejo, do fim do mundo, apoca- 
lipse." (idem, p. 233) Este tom crítico, sobretudo com relação à psiquiatria de filiação freudiana, é testemunho do pertencimento d'O Anti-Édipo à conjuntura teórica de seu tempo, sobre a qual os autores procuravam produzir efeitos diretos. ${ }^{1}$

Sob o fracasso dos acontecimentos de maio de 68 em trazer mudanças concretas, os autores procuram os motivos que fariam o indivíduo abrir mão de sua liberdade em favor da dominação política. Portanto, Deleuze e Guattari (2011, p. 158) escrevem para uma sociedade que reprime o desejo, e mais que isto, que funciona de tal forma que encontra algo melhor do que a repressão, para que até a repressão, a hierarquia, a exploração e a sujeição sejam desejadas pelos indivíduos. Este algo é identificado com a teoria do inconsciente representacional que se subordina ao significante de Édipo. A polêmica com a psicanálise presente neste livro dá-se no sentido de uma denúncia à repressão ilegítima do inconsciente, que, posteriormente, é abandonada em função de um projeto maior, "Capitalismo e esquizofrenia". Cabe notar que a conjunção entre um estudo econômico - capitalismo - e um estudo psicanalítico esquizofrenia - não constitui, por si, uma novidade no momento de lançamento da obra.

A relação entre formações sociais e psíquicas (freudismo e marxismo) foram também estudadas por Wilhelm Reich em A Revolução Sexual (1936), Herbert Marcuse em Eros e a Civilização (1955), ou até mesmo, Michel Foucault em História da Loucura na Idade Clássica (1961). A especificidade da obra está no tratamento indireto com que os autores abordam o freudomarxismo. A proposta é seguir outra via que não simplesmente uma psicanálise da economia política ou uma crítica marxista da psicanálise, que partem de uma oposição de natureza entre estrutura econômica e psíquica. A diferença existe, porém, com a condição de que seja fruto da repressão social do desejo, sendo um resultado da conjuntura política da sociedade capitalista. Trata-se de uma tripla crítica: ao discurso psicanalista (inspirada nos estudos de Nietzsche (1999) sobre o surgimento da figura do padre nas culturas judaicas e cristãs em A Genealogia da Moral); ao discurso marxista (encarregando-se de um problema sem solução viável legado pelo marxismo, a saber, a invenção de uma forma de centralismo capaz

de conciliar a coerência unitária da luta revolucionária e a máxima diversificação das experimentações políticas, teóricas e práticas, de maneira a evitar tanto a hierarquização burocrática dos aparelhos de partidos quanto o sectarismo dos grupos de ultraesquerda (SIBERTIN -BLANC, 2010, p. 147)); e, por fim, ao discurso de articulação destas duas tendências analíticas, o freudomarxismo (através da criação de uma nova teoria do desejo, de modo a fazer da intervenção política no campo social o vetor de experimentações e de transformações de si, e, destas experimentações, o meio de renovar os modos de percepção, de inteligibilidade e de intervenção material no campo social (idem, p. 149-150). ${ }^{2}$

Esta articulação entre "campo social" e "transformações de si” é de fundamental importância para compreender-se o registro de significação da produção, apresentada acima em oposição ao de expressão. Cabe notar que até mesmo o ato da leitura se transforma em terreno para experimentação no campo político:

ler um texto nunca é um exercício erudito à
procura dos significados, ${ }^{3}$ e ainda menos um
exercício altamente textual em busca de um
significante, mas é um uso produtivo da má-
quina literária, uma montagem de máquinas
desejantes, um exercício esquizóide que extrai
do texto sua potência revolucionária. (DELEU-
ZE; GUATTARI, 2011, p. 144-145)

A partir desta citação pode-se apreender a ambiguidade própria ao texto literário. De certa forma, todo texto possui uma potência revolucionária ao estar no domínio da criação, do livre curso produtivo do desejo; no entanto, possui também um caráter reacionário ao orbitar em volta de um significante já constituído (despótico). O mero fato de incluir em seus enunciados o pronome "eu" insere o texto sob o significante de Édipo, que pressupõe a síntese subjetiva como naturalmente dada, não construída historicamente. É por isto que "a única literatura é aquela que faz do seu embrulho uma armadilha, fabricando uma falsa moeda, explodindo o superego de sua forma de expressão e o valor mercantil de sua forma de conteúdo" (idem, p. 181). Todo texto é necessariamente ambíguo; entretanto, somente aquele que consegue, apesar de jogar com o significante, supe- 
rá-lo e revelá-lo, está propriamente no domínio da literatura. É desta forma que Balzac consegue representar a centralidade do dinheiro na sociedade burguesa do século XIX apenas descrevendo a mudança de tratamento que o Sr. Grandet recebe após enriquecer:

Se, no início, algumas particularidades de sua vida deram lugar ao ridículo e à zombaria, a zombaria e o ridículo já se haviam dissipado (...). Suas palavras, seu vestuário, seus gestos, seu modo de piscar constituíam lei na região, onde qualquer um, após havê-lo estudado como um naturalista estuda os efeitos do instinto entre os animais, teria reconhecido a profunda e silenciosa sabedoria de seus menores movimentos. (BALZAC, 1950, p. 219)

Fala-se aqui em significante de Édipo, pois esta é a forma sob a qual o desejo se apresenta empiricamente. Dois aspectos da instituição familiar garantem que o complexo de Édipo se torne efetivamente estruturante para a vida subjetiva: a família funciona simultaneamente como sistema de reprodução dos produtores (divisão social e técnica do trabalho) e como código desta produção e de seus produtores (a entrada na produção social se dá a partir do ponto de vista da filiação e da paternidade). Isto pode ser observado mais claramente ao comparar-se a família civilizada com a família selvagem:

As famílias selvagens formam uma práxis, uma política, uma estratégia de alianças e de filiações; formalmente, elas são os elementos motores da reprodução social; elas nada têm a ver com um microcosmo expressivo; o pai, a mãe, a irmã sempre funcionam aí como outra coisa além de pai, mãe e irmã. (DELEUZE; GUATTARI, 2011, p. 221, grifo nosso)

No modo de produção capitalista, onde a produção social passa para a dominação do capital, o familismo, como forma de subjetivação do desejo e de sua enunciação, encontra a possibilidade de estabelecer-se na medida em que a instituição familiar não tem mais nenhuma importância do ponto de vista da reprodução social, uma vez que ela perde toda incidência estratégica e se encontra "fora" do campo social que a determina. Isto significa que a família cessa de conferir sua forma social à reprodução econômica, e torna-se forma socializada de reprodução de um material humano indiferenciado. A reprodução social passa cada vez mais para o processo do capital como forma social de reprodução autônoma em relação aos antigos códigos de aliança e de filiação. A família não determina mais por ela mesma a posição social dos homens, que será determinada pelas exigências internas de acumulação e de valoração do capital. Cada indivíduo deve ocupar um lugar na produção social, e é apenas por vias subjetivas que se dá a retransmissão dos códigos de socialização do desejo. Assim, tem-se que:
A família devém o subconjunto ao qual se apli- ca o conjunto do campo social. Como cada um tem um pai e uma mãe a título privado, é um subconjunto distributivo que simula para cada um o conjunto coletivo das pessoas sociais, que fecha o domínio e emaranha suas imagens. Tudo se assenta sobre o triângulo pai-mãe-fi- lho, que ressoa respondendo "papai-mamãe" a cada vez que as imagens do capital o estimulam. (...) No conjunto de partida há o patrão, o che- fe, o padre, o tira, o fiscal da receita, o soldado, o trabalhador, todas as máquinas e territoriali- dades, todas as imagens sociais da nossa socie- dade; mas, no conjunto de chegada, só há, no limite, papai, mamãe e eu... (idem, p. 351-352)

Desta forma, tudo o que se passa na esfera do desejo, com seu caráter essencialmente social, toma a forma de uma das figuras familiais. No entanto, se Édipo exprime efetivamente o desejo, cabe perguntar pela incidência do recalcamento sobre ele. $\mathrm{O}$ argumento utilizado por Freud retoma uma observação de James George Frazer, segundo o qual "a lei só proíbe o que os homens seriam capazes de fazer sob a pressão de alguns dos seus instintos; assim, da proibição legal do incesto, devemos concluir que existe um instinto natural que nos impele ao incesto" (idem, p. 155). Esta inferência - "algo é proibido, logo, é desejado" - é fortemente criticada por Deleuze e Guattari (2011), pois demonstra uma confiança extrema na lei. Este culto à lei na sociedade capitalista leva a uma inversão: se ela diz que os indivíduos não devem matar seu pai e casar-se com sua mãe, será justamente isto que o sujeito desejará fazer. De fato, foi visto que o desejo tende a explodir as instituições, mas 
é completamente falso inferir de uma proibição a natureza do que é desejado:

Pode acontecer que a lei proíba algo de perfeitamente fictício na ordem do desejo ou dos "instintos", para persuadir seus sujeitos de que eles tinham a intenção correspondente a essa ficção. É justamente esta a única maneira que a lei tem de pegar fundo a intenção e de culpabilizar o inconsciente. (idem, p. 156)

Assim, a psicanálise é caracterizada como obra de repressão burguesa mantendo a sociedade sob o jugo do incesto, e não dando nenhuma alternativa que dê fim a esse "problema". Ao invés de abrir-se para conexões plurívocas, ela se fecha num impasse de univocidade. Todas as cadeias do inconsciente são ligadas a Édipo, enquanto significante despótico. Toda produção desejante é esmagada, substituída por uma simples representação. "Édipo é a reviravolta idealista" (idem, p. 78). Ele abstrai todo o conteúdo político, social, histórico que o delírio tem, caracterizando a libido como não tendo nenhuma relação com estas coisas.

Disto decorre a denúncia dos autores de ser o incesto uma dedução lógica da razão, uma ideia constituída a partir da concepção de recalcamento e sua relação com o desejo. Ele tem natureza conceitual. Sendo uma ideia introduzida na esfera passional, ele é tomado por princípio de ação. No entanto, ao provar-se que sua origem se dá no âmbito do conceito, já se prova seu não pertencimento ao inconsciente, que não tem nenhuma relação com o ideal, sendo pura ação e não estando sob o domínio de nenhum significante. "O inconsciente nada diz, ele maquina. Não é expressivo ou representativo, mas produtivo" (idem, p. 239).

O incesto é impossível, não no sentido em que o real o seria (é fisicamente possível ter relações sexuais com a filha, a impossibilidade aqui é no sentido em que o simbólico o é): o nome "filha" enquanto instituição social exclui completamente o nome "amante", também enquanto instituição social. Sendo que

no ato do incesto, podemos dispor de pessoas, mas elas perdem seu nome, já que esses nomes são inseparáveis da proibição que os interdita como parceiros; ou então os nomes subsistem, mas designam tão somente estados intensivos pré-pessoais, que bem poderiam "estender-se" a outras pessoas, como quando se chama mamãe à mulher legítima, ou irmã à esposa. (...) É que nunca podemos fruir simultaneamente da pessoa e do nome - o que seria, porém, a condição do incesto. (idem, p. 215)

A força do significante, que passa sempre pelo valor social das pessoas, institui um não lugar para a situação de incesto. Por isto, ele é eleito como o objeto máximo da autorrepressão do desejo.

\section{2. $O$ incesto na literatura brasileira: o lugar privilegiado de Marta}

No caso da literatura brasileira, o incesto, enquanto assunto motivador da obra literária, é algo quase inédito. Há casos mais recentes em que serve de motor casual do enredo, atuando como acessório de uma questão superior, como nos exemplos maiores da Crônica da casa assassinada, de Lúcio Cardoso (1979), e de Lavoura arcaica, de Raduan Nassar (2009). ${ }^{4}$ Há, ainda, casos em que o incesto desempenha um papel ainda menos significativo, evocado apenas como empecilho ao enlace amoroso entre protagonistas, sob o signo do Romantismo de Helena, de Machado de Assis (1959); ou como fator de desequilíbrio biológico e motivo para o estudo do temperamento da personagem, sob o signo do Naturalismo de O homem, de Aluísio Azevedo (2005), e de Inverno em flor, de Coelho Neto (1958).

No entanto, uma obra nacional pode ser vista, no tocante ao elemento central do incesto, como construída e inteiramente motivada por ele: trata-se do romance Marta, de Medeiros e Albuquerque, publicado em 1920 , e hoje quase desconhecido. ${ }^{5}$ Seu autor, lembrado negativa e rapidamente em compêndios de literatura por "mostras assíduas de imaginação vasqueira e sensualona" (BOSI, 2008, p. 270), ou ainda, como introdutor hesitante do Simbolismo no Brasil na década de 1880, com Canções da Decadência e Pecados, "entre vários focos de estímulo, numa hesitação sintomática: sentimentalidade romântica, erotismo, poesia social, materialismo, nevrose..." (MOISÉS, 1969, p. 52), parece ter sofrido o esquecimento programático de muitos 
outros escritores da virada do século, destronados pelos modernistas nas décadas de 1920 e 1930. Como observa Wilson Martins (1999, p. 615), "a leitura de sua obra crítica [revela], em todas as páginas, a incompreensão, a ironia, o antagonismo essencial que o separavam do Modernismo", e que foram os grandes responsáveis pelo esquecimento dos bons momentos de sua obra. É o que ocorre, ainda uma vez, com o romance Marta, que, para além de uma obra "vasqueira e sensualona", mergulha nas nevroses de nossa belle époque e observa, no tedioso cotidiano de uma burguesia passadista, os frágeis limites existentes entre as aparências e o desejo. ${ }^{6}$

O primeiro capítulo é, neste sentido, sintomático, descrevendo panoramicamente o ocioso cotidiano do Hotel White, na Tijuca. Menciona o pisco João Caldas, que "estava bastante rico e parecia feliz", e viera ali "saber a vida de uns e outros" em meio a leituras de Paul Bourget, Marcel Prévost etc. (ALBUQUERQUE, 2013, p. 27). Seu interlocutor, Leopoldo Braga, "ainda 'mais urso' que o amigo", em viagem por motivos de saúde, "era - pode-se dizer, teoricamente - advogado; mas advogado de escassa clientela. Morreu-lhe o pai, que tinha uma pequena fortuna, e ele casou-se com uma bela moça nas mesmas condições e passou a viver uma vida quase inteiramente ociosa" (idem, p. 28), coroada pela existência da filhinha, Marta, então com dois anos de idade e sua companheira de viagem. Outros hóspedes do hotel são ainda enumerados - diplomatas do Chile e da Itália, grupos de moças e senhoras - restando a descrição pormenorizada do zelo de Leopoldo para com a criança, e seu cuidado por conhecer "miudamente as datas exatas em que ela tivera o seu primeiro sorriso, em que lhe nascera o primeiro dente, em que dera o primeiro passo" (idem, p. 29). Logo percebe o leitor ser este advogado o protagonista da obra, bem como sua relação com a filha o assunto do livro.

Apresentado pelo Caldas, conhece Leopoldo D. Margarida Seixas Gomes, esposa de um bruto comerciante. ${ }^{7} \mathrm{~A}$ atenção maternal da senhora Seixas Gomes para com sua filha desperta o interesse do advogado, que logo se apaixona pela amiga: "Essas palavras maternais, disse-as com uma voz grave e carinhosa - gravidade e carinho que se insinuaram tanto mais no espírito de Leopoldo, quanto ele próprio achava a observação justa
(...). Havia alguma coisa de conjugal na conversa dos dois" (ALBUQUERQUE, 2013, p. 52). Imediatamente, surge o espectro de um segundo enlace amoroso em sua vida, já distante de sua esposa e atento unicamente à formação física e moral da filha. Está claro, pois, que o sentimento de fidelidade ao matrimônio coloca-se em um patamar inferior à responsabilidade para com a filha, o que, por sua vez, legitima o adultério, com base em uma transferência de carinho materno.

No entanto, se, por um lado, Margarida pode cuidar da sensibilidade da menina e recomendar-lhe uma dieta e um cotidiano saudáveis, não pode igualmente, do ponto de vista ético, acrescentar-se à sua vida sem prejuízo do recato familiar de Leopoldo. Novamente, é de Margarida - e não de Leopoldo, espectador da vida em todas as suas minúcias, como bom advogado "teórico" - a decisão pelo rompimento, com base nos efeitos negativos que a relação traria para Marta: “-Tu tens uma esposa que te ama, uma filha a quem adoras. Com que direito eu te roubaria a elas? (...) Se partisse contigo, não perderia coisa alguma; lucraria tudo. E tu? Pensa em Marta!" (ALBUQUERQUE, 2013, p. 61).

Após o rompimento entre os amantes, Leopoldo recebe uma proposta de emprego e instala-se em $\mathrm{Pa}$ ris com a mulher e a filha. A estadia do advogado na metrópole prolonga-se por 20 anos, durante os quais se torna viúvo e começa a viver um cotidiano dissipado, dividido entre os cuidados com Marta e os pequenos amores (não mais adúlteros) passados em uma garçonnière. Dispondo de tempo livre e de uma ocupação quase inteiramente "teórica" - a de correspondente de uma firma jurídica -, Leopoldo preenche seus dias com as minúcias de seus encontros amorosos, registrando em diário as intimidades das jovens parisienses e fazendo-se passar por verdadeiro prestidigitador da alma feminina. Na verdade, dispõe de seus contatos jurídicos para colher informações nas delegacias sobre o passado de cada mulher, gozando antes o controle integral sobre o passado e o presente das parceiras que a consequente relação material do sexo. Desta forma,

Leopoldo não era (...) um grande sensual. Não passava, mesmo na sensualidade, de um intelectual. Tinha, lidando com tantos cérebros e 
corações de mulheres, o prazer de um hábil mecânico que gosta de ver funcionar máquinas delicadas, de que aprecia o movimento e a entrosagem das peças. Um dos seus deleites era a sua grande correspondência. Se aquelas a quem ele se dirigia pudessem um dia remexer à vontade no armário em que o Leopoldo guardava, classificadas, todas as cartas que recebia e muitas vezes as minutas das que expedia, ficariam espantadas. Alguns desses dossiês guardavam peças interessantes: notas de agência de polícia particular, contendo, mais ou menos, a biografia da pessoa; análises grafológicas... E na "ficha" de todas, porque todas tinham as suas fichas, lia-se, diante da data de cada visita, o que ela havia feito, a descrição sumária do vestido e do chapéu com que estava, e, às vezes, a menção de qualquer incidente curioso. (ALBUQUERQUE, 2013, p. 77-78) ${ }^{8}$

Não há, portanto, limites entre o público e o privado para as pulsões de Leopoldo - que se serve de sua posição "legal" na firma para satisfazer um apetite fetichista, capaz de fragmentar o contato interpessoal em fichas e minutas, e, neste plano, sequestrar e monopolizar a esfera do gozo sexual. Se observado o comportamento de Leopoldo para com Marta e o cuidado excessivo empenhado na educação da filha, desponta com precisão a origem deste empenho minucioso pelo controle da mulher. Compare-se, pois, o trecho acima, com o abaixo, referente aos planos iniciais delineados para a formação da filha:

Acumulava notas: "se ela manifestar tal tendência, cumpre corrigi-la deste ou daquele modo." E como se a tendência a corrigir fosse um caso concreto, uma moléstia declarada que ali estivesse na sua presença, ele punha em ordem os meios de combatê-la, expondo sucessivamente: "meios físicos, meios intelectuais, meios emocionais". Sob cada rubrica havia um certo número de exercícios indicados: "obrigála a isto ou àquilo", "fazê-la estudar determinada disciplina", "apreciar tal ou qual obra de arte". Para outro, aquela ocupação seria pueril. Para ele, era um encanto: fazia-o pensar na sua Marta. A cada conselho que escrevia, evocava-a diante dos seus olhos: via-a executando, graciosa, o exercício, estudando gravemente a disciplina, palpitando à emoção artística cuidadosamente notada. (idem, p. 49)
A equiparação dos trechos é valiosa, uma vez que detecta com alguma precisão o procedimento incestuoso de Leopoldo. O prazer de registrar as minúcias do comportamento da filha, capaz de antegozar a imagem dócil e obediente aos menores caprichos do pai, é transferido para as amantes parisienses. Estas, por sua vez, "iam verdadeiramente atordoadas, sem saber explicar aquele homem estranho, doce, meigo, capaz de perscrutar tão singularmente coisas que elas não podiam crer que ele normalmente conhecesse" (idem, p. 79). De fato, "normalmente", seria difícil que despertassem em poucos dias o interesse perscrutador do velho advogado com tamanha ênfase - explicável apenas por sua conexão com o amor à filha, reproduzida, em segundo grau, na feição estarrecida e submissa de cada uma de suas amantes.

Leopoldo, todavia, é inconsciente da origem incestuosa de seu "diabólico laboratório de seduções" (idem, p. 78), e somente percebe a importância material da imagem da filha quando Marta vem a falecer, acometida de uma meningite. A tragédia maior para o advogado, maior que sua morte, era o fato de haverem cortado seus cabelos, "os longos e sedosos cabelos", acrescido da ausência de um retrato da falecida, que a avivasse na memória: "Minha filha, que era tão bonita! tão bonita!" (idem, p. 82). A fixação de Leopoldo pela beleza de Marta é tamanha que Ivan Teixeira (2013, p. 11) chega a sugerir um intertexto entre o romance e o conto " $\mathrm{O}$ retrato oval", de Edgar Allan Poe. ${ }^{9}$ De fato, o amor alucinado de Leopoldo pela filha é agravado pela ausência de um retrato da moça:

Queria reconstituir na imaginação a figura da moça, quando ela ostentava a maravilha dessa cabeleira castanho-escura, naturalmente ondulada; mas não podia. Uma aberração cruel do seu espírito só lhe permitia ver bem a cabeça da filha lisa e lustrosa, como a calva de um velho! (...) E, no meio do desespero imenso em que jazia, a falta do retrato de Marta foi mais uma ponta, mais um acúleo acerado que o feria. (...) Sem o auxílio material de um retrato, tinha medo de perder a noção dos traços da filha e seria então como se, por sua vez, ele a matasse... Era uma tortura sem nome! (ALBUQUERQUE, 2013, p. 83-84) 
Muito embora a ausência do retrato de Marta sugira a Teixeira (2013) uma comparação remota com $O$ retrato de Dorian Grey, de Oscar Wilde,10 Leopoldo sente-se horrorizado, e não embevecido, ao encontrar o retrato perfeito da filha, sob o modelo de "uma cançonetista depravada", que em nada reproduz a aura de pureza tão apreciada em Marta, e "parecia-lhe poluir a memória da filha evocando-a através da figura dessa cançonetista de baixo estofo, para quem o palco era apenas o anúncio de que se alugava a quantos a queriam..." (idem, p. 84). Ainda uma vez, Leopoldo demonstra ignorar a razão sexual de sua fixação pela filha, e abomina uma comparação entre ela e a famigerada cantora. Percebe-se, pois, a dissociação entre o significante da beleza de Marta, reproduzida no retrato "fielmente" pela cantora, e o significado profundo de Marta para Leopoldo - ambivalente, alçando-se à pureza inatingível e descaindo no mais baixo e carnal dos prazeres, indiretamente, pelos diários e fichas da garçonnière.

Morta Marta (a impossibilidade do desejo parece ressignificar o nome próprio), Leopoldo retorna ao Brasil e depara-se, ao chegar, com uma moça igual a Marta, e que logo vem a saber, por intermédio da ex amante, ser o produto do antigo romance no Hotel White. Margarida, em seu leito de morte, faz Leopoldo jurar cuidar de Marta (é este o nome da segunda filha, como espectro a persegui-lo além do túmulo), porém sem jamais revelar-lhe a paternidade, a fim de preservar a santidade de sua memória. Obviamente, as visitas constantes de Leopoldo à filha, bem como sua alegria em sua presença, são mal interpretadas pela sociedade, que ignora o verdadeiro elo entre ambos: "E, como se uma venda lhe houvesse caído dos olhos, Leopoldo começou então a recordar fatos, alusões, atitudes de várias pessoas... - Que horror! - E pensar que ele estava com os lábios trancados por dois soleníssimos juramentos a uma moribunda!" (idem, p. 141).

Gradualmente, Leopoldo passa a entender a encruzilhada moral de sua vida, muito obstante tenha em seu espírito, ainda, a primeira Marta, morta em Paris, mesclada à segunda, filha de Margarida:

Várias vezes em festas diversas, fotógrafos de revistas ilustradas haviam tirado instantâneos em que Marta figurava. (...) Tinha assim vários retratos dela. Tomando um deles, um dos mais recentes, em que ela assistia a uma corrida de cavalos, Leopoldo contemplou-a devagar. Já então, quando ele queria evocar a primeira Marta para poder comparar as duas, essa operação mental se lhe tornava impossível. Confundia-as. A de agora era, portanto, para ele duplamente filha: tinha absorvido a imagem da outra. (idem, p. 123)

O procedimento é cômodo, e permite o moralismo estreito de Medeiros e Albuquerque - que admite a construção do enredo em torno de um pai incestuoso, com base em sua completa inconsciência (entendida em termos de inocência) perante seu crime. A crítica central da obra à mesquinhez do meio carioca das primeiras décadas do século XX é, pois, dirigida não a este pai que luta consigo próprio, fiel cumpridor de uma promessa a uma morta, além de pai zeloso de duas filhas, mas sim à prática do casamento arranjado, que acelera romanticamente a trama e apressa a morte de Leopoldo, já de meia idade. Isto tudo porque Seixas Gomes, pai "verdadeiro" de Marta, exige que ela se case com um de seus companheiros de noitadas, jovem estroina e imoral, chamado Andrade. Ergo, o dilema falsamente central do livro: o que é mais imoral - casar-se um bom pai com sua filha, para livrá-la das garras de um padrasto interesseiro e de um noivo medíocre, 11 cometendo incesto; ou deixá-la à própria sorte, sabendo-a desgraçada de antemão?

A pergunta está claramente mal colocada, uma vez que Leopoldo não é inocente, mas apenas inconsciente do desejo que (o) possui. De qualquer forma, a filha, ignorando a razão do silêncio do velho e bom amigo, foge para sua fazenda pouco antes do casamento com Andrade, sendo logo estampada nos jornais como raptada por Leopoldo:

O que se passava dentro de Leopoldo era uma luta trágica. Casar ou não casar? Casar - era o horror dos horrores, era a monstruosidade do mais monstruoso dos incestos. Mas não casar... Para uso da sociedade, Marta estava desonrada. Fossem lá convencer a maledicência do mundo que a moça, quando chegara à fazenda, não o encontrara nela. Só havia um meio 
de lavar essa mancha. (...) Demais, se ele não se casasse e não dissesse porque o não fazia, Marta ficaria com uma mancha indelével. Pior, porém, seria se ele dissesse: não só violaria o juramento sagrado que fizera a uma moribunda, como desonraria a sua memória, maculando também o nome da filha. (ALBUQUERQUE, 2013, p. 165)

Neste sentido, ao suicidar-se após o casamento incestuoso com Marta - jamais consumado, à imagem e semelhança de boa parte de seus affaires em Paris -, o protagonista não deixa de consumar, à segunda potência e dentro dos limites autorizados pela sociedade, aquilo mesmo que não podia fazer por conta própria. Ou seja: casa-se com aquela que mais amou em vida, concretizando, ao menos no papel (papel da certidão, papel das fotografias, papel das fichas e dos estudos grafológicos), o que jamais poderia concretizar sem cometer o "horror" que traz consigo.

Afinal, morre Leopoldo, despertando obviamente grande tristeza em Marta - o que não importa tanto, diga-se de passagem, quanto o respeito e afeto da opinião pública, representada por uma velha empregada da casa, "siá Mariana”, cujo lamento encerra o romance: "E o que mais se ouvia era a queixa boa e doce da velhinha: - Ele era tão bom! Tão bom!".

Ademais, a descrição da morte de Leopoldo apresenta um caráter simbólico, diretamente ligado à prática psicanalítica, e que lança nova luz à sua memória - de bom pai e de mau amante:

Leopoldo estava deitado num largo e fofo divã inglês. Era um divã forrado de couro verde, muito baixo. A mão, em que havia um revólver, tocava o chão. Leopoldo tinha encostado a boca da arma por baixo do queixo e disparado. A bala varou a língua, varou o céu da boca, entrou no cérebro, varou o crânio e, saindo, entrou no encosto do divã. O rosto estava absolutamente calmo. O sangue que saía - saía pela ferida que ficava perto do colarinho e mancha$v a-o$. (ALBUQUERQUE, 2013, p. 168, grifos nossos)

O divã é o instrumento da psicanálise por excelência e está ligado a uma promessa de libertação pela língua / fala. O trajeto do tiro que mata Leopoldo vai de sua língua até o divã, envolvendo ambos em uma libertação pela morte. Seu rosto imaculado, "absolutamente calmo", descai no movimento sutil de suas expressões, não mais obedecendo a instinto algum. O fluxo de sangue mancha tão somente o colarinho branco, símbolo do asseio social, e evoca o atentado que Leopoldo comete à solidez da instituição familiar na simbologia da mancha de sangue. A mão que toca o chão sela o pertencimento de Leopoldo à surda contraposição dos instintos em relação à pureza de seus ideais em vida ("Puríssima te achei, puríssima te deixo" são as primeiras palavras da carta que deixa para Marta). Através desta simbologia, pode-se visualizar o pertencimento do personagem Leopoldo à forma edipiana e o quanto estava ele sujeito aos códigos sociais dominantes, tendo interiorizado a repressão do desejo pela filha. Desejo, por sua vez, que nunca fora sexual, mas desejo pelo nome, pela própria impossibilidade da existência do desejo (fichas, retratos, cabelos etc.). Medeiros e Albuquerque, através de uma trama um tanto quanto rocambolesca, apresenta uma situação em que o incesto torna-se socialmente possível, havendo consentimento da sociedade por meio da ignorância da paternidade. E é justamente esta situação excepcional em que há possibilidade de concretização do incesto enquanto ato físico que revela a verdadeira natureza do incesto: o controle sobre o desejo através da soberania da lei.

A proibição procede induzindo uma imagem desfigurada e deslocada do que é realmente proibido ou desejado. Sua função é culpabilizar o inconsciente. A relação de Leopoldo com a filha faz com que ela sirva de móvel para o desejo, e a proibição da sexualidade enquanto ato de fala desperta-lhe a sexualidade concreta, a qual lhe passa sempre pela via do controle, da soberania da lei. É a lei que o faz gozar. Marta ensina uma das principais lições de $O$ Anti-Édipo: a autorrepressão do desejo não inibe a sexualidade, apenas a desnaturaliza, coloca-a em termos de família, em função de um controle dos indivíduos, de um apagamento da potência produtiva do inconsciente que naturalmente se insubordina às forças dominantes.

Assim, no romance, salvam-se as aparências; salva-se também a honra de Marta. Perde-se, todavia, o "bom" Leopoldo, para benefício de todos, e manuten- 
ção do status quo da pacata família burguesa. Aqui está o cerne da crítica do romance, escrito no tom do toma lá dá cá do Realismo oitocentista: confrontado com uma sociedade hipócrita, Leopoldo deve encarnar até o fim um ideal hipócrita de família, entremeado de relações extraconjugais, de casamentos arranjados, de garçonnières e de muitos outros expedientes "permitidos" pela opinião.

Certamente, Leopoldo não se preocuparia com nada disto: Marta sobrevive (ao menos, uma delas), e é ela, não ele, afinal, quem serve de título à obra.

\section{Conclusão}

Pelo que se passou em revista de um ponto de vista conceitual (via Deleuze e Guattari) e de um ponto de vista analítico (via discussão de trechos pontuais de Marta), conclui-se o viés crítico de Medeiros e Albuquerque em assinalar algumas das hipocrisias da belle époque brasileira. Neste sentido, "denuncia-se uma sociedade moralista" (SALVADOR, 2012, p. 389) que interpreta o desejo como bem lhe apraz.

De certa forma, é estranho que tal crítica tenha partido de um escritor como Medeiros e Albuquerque, ele próprio uma instituição nas duas primeiras décadas do século XX, colaborador ativo nos primeiros anos do governo republicano (as letras do Hino são, inclusive, de sua autoria) e fundador da Academia Brasileira de Letras (é o primeiro ocupante da cadeira n. 22). ${ }^{12}$

Por outro lado, é mais que compreensível que Marta seja mesmo de sua autoria: afinal, trata-se de uma questão de posse da filha pelo nome, i.e., simbolicamente; e foi Medeiros um de nossos maiores cultores da língua, além do autor da primeira proposta entre nós de uma reforma ortográfica. Entender o quanto se imbricam a posse incestuosa e o culto fetichizado do cânone pós -parnasiano como um grande círculo lentamente autodevorador dos anos anteriores ao Modernismo, é, talvez, a melhor forma de captar, na íntegra, o valor de sua obra.

\section{Notas}

1. Para um estudo mais aprofundado da recepção da obra, ver Sibertin-Blanc (2010).

2. Sobre esta questão da especificidade da abordagem freudo-marxista, ver Deleuze (2002, p. 384-385).

3. Esta reflexão sobre o caráter político da leitura será desenvolvida em Mille plateaux (1980), no capítulo/ platô 4 , "Postulats de la linguistique", em que os autores apresentam o conceito "mot d'ordre".

4. No primeiro, enquanto prova da decadência de uma família conservadora do interior de Minas Gerais, marcada pela relação falsamente incestuosa entre Nina e seu "filho" André (na verdade, filho de um amor secreto entre a cunhada de Nina e o jardineiro da chácara); no segundo, enquanto válvula de escape ao moralismo estreito de um patriarca rural, que morre de tristeza ao saber do incesto cometido por dois de seus filhos, André e Ana, quando do retorno de André à fazenda, numa clara revisão da parábola bíblica do filho pródigo.

5. À edição de 1920 da Livraria Francisco Alves, seguiuse a segunda edição, de 1922, pela mesma casa, e a terceira, em 1932, editada pela Renascença. O romance foi recuperado apenas recentemente (2013) pela coleção Reserva Literária da EDUSP, utilizada neste trabalho como texto-base das citações. Trata-se do primeiro romance do escritor, que ainda publicaria em 1921 Mistério (em parceria com Viriato Correia, Afrânio Peixoto e Coelho Neto) e em 1933 Laura.

6. Segundo Vitor Celso Salvador (2012, p. 388), autor da única dissertação disponível no Banco de Teses da CAPES sobre Medeiros e Albuquerque, "Marta possui visíveis evidências da psicanálise de Freud, pela manifestação do desejo inconsciente de Marta pelo pai Leopoldo, revelando o Complexo de Electra (quando a filha se interessa pelo pai)." É evidente que, como se verá a seguir, a presença do pensamento freudiano é uma constante, muito embora não se possa falar em um Complexo de Electra tanto quanto do desejo incestuoso de Leopoldo pela filha. De toda forma, é importante ressaltar que Medeiros e Albuquerque tenha enfocado "o tema da atração erótica entre pai e filha [...] no momento mesmo em que o Dr. Franco da Rocha publicou em São Paulo O pan-sexualismo, nome depreciativo com que se costumava designar, àquela altura e muito depois, a doutrina de Freud" (MARTINS, 1978, p. 181).

7. A cena das bodas entre Margarida e Seixas Gomes é talvez antológica pelo mau gosto com que apresenta a animalidade do marido - bêbado, bruto, a violentar a esposa como um animal, rolando pelo chão. $\mathrm{O}$ ápice da cena, em que Seixas vomita sobre a mulher uma golfada de vinho e desmaia sobre seu corpo é um 
claro intertexto com a cena animalizada de sexo entre Gervaise e Lantier sob o vômito simbólico de Coupeau em L'assommoir, de Émile Zola, tão bem apontada por Antonio Candido (1991, p. 126) a propósito de uma cena semelhante presente também n'O Cortiço.

8. É curioso observar o fato de que, inteiramente oposto a Leopoldo, Medeiros e Albuquerque relate uma de suas conquistas amorosas em Quando eu era vivo..., pautada inteiramente no anonimato estabelecido entre si e uma francesa, encontrada três vezes por acaso. O caso é precedido pelo seguinte esclarecimento: "(Este caso eu o referi resumidamente no meu romance Marta)” (ALBUQUERQUE, 1945, p. 285). No romance, o encontro "real" é reproduzido na primeira relação sexual entre Leopoldo e Margarida, ainda que "resumidamente". Desta forma, percebese o quão tênue pode ser a barreira que separa a literatura da vida, e o quanto persiste o autor no limite entre ambas.

9. Como se sabe, o conto desenvolve a fixação de um pintor pela beleza de sua amada, que, ao tentar reproduzir fielmente seu semblante através de horas intérminas de serão - que desgastam e adoentam a moça - acaba por percebê-la morta, tão logo acaba seu quadro. Trata-se, pois, de uma transplantação da vida à arte, em que, para o benefício da segunda, a primeira deve sacrificar-se em um longo ritual. A comparação é fortuita, uma vez que assinala a fixação pela imagem feminina com base em um desejo incontido, de ordem amorosa (entre um homem e uma mulher, aqui equiparados ao segundo binômio, pai e filha).

10. Apesar da atmosfera decadentista comum a ambas as obras, não há em Marta uma mesma absorção moral da protagonista pelo quadro (enquanto registro ácido de crítica ao dandismo, muito mais presente na vida inglesa que na brasileira), nem a mesma ciência do Mal, executado egoisticamente por Dorian.

11. A truculência de Seixas Gomes é reiterada, para além de seu comportamento com Margarida, pelo ato de destruir as fotografias de Leopoldo do álbum de visitas da família, em movimento inverso àquele do pai verdadeiro de Marta. Esta, tal como Leopoldo, agarra-se às fotografias para salvá-las: "Seixas Gomes adiantou-se para o álbum de retratos, procurou o de Leopoldo, tirou-o e ia rasgá-lo. Num gesto brusco, Marta arrancou-lho das mãos. Essa audácia da filha levou Seixas Gomes a um verdadeiro paroxismo. Avançou para Marta e tomou-lhe a fotografia com tanta fúria que, empurrando a moça, ela foi cair à distância, no chão. Seixas Gomes picou o retrato e atirou os pedaços ao tapete da sala. Depois, voltando-se para a filha ainda caída: - Daqui a quinze dias está casada!" (ALBUQUERQUE, 2013, p. 146). Por meio deste episódio, nota-se a correspondência afetiva de Marta para com Leopoldo, bem como certa hereditariedade, de tom naturalista, do comportamento.

12. Medeiros chegou mesmo a impedir o discurso de posse de Emílio de Menezes, famoso por sua boemia, corrigindo a fala do colega tantas vezes que Emílio jamais chegou a ocupar a vaga de Salvador de Mendonça, para a qual fora eleito. Plínio Doyle (1999, p. 91-94) discute o caso com vagar em Uma vida, onde aponta a oposição truculenta de Machado de Assis e de Medeiros e Albuquerque à candidatura de Emílio. Sobre Medeiros, diz ainda: "Medeiros e Albuquerque, que era o presidente, mandou, ele mesmo conta em Quando eu era vivo (1942), que fossem cortadas as alusões a Afrânio Peixoto e a Oliveira Lima, além de outras alterações. Emílio cortou apenas uma. Medeiros insistiu, e Emílio mandou dizer que cortaria tudo que fosse ordenado, mas que, na hora de proferir o discurso, leria o que havia inicialmente escrito; e Medeiros replicou que não tentasse essa experiência" (DOYLE, 1999, p. 93). O relato de outras farpas do escritor está presente no artigo de Salvador (s/d), dirigidas a Gomes Bastos, a D. Pedro II e ao mesmo Emílio de Menezes. De uma forma ou de outra, está claro que "não são os julgamentos literários de Medeiros e Albuquerque que interessam à história da crítica, nem mesmo à história da literatura brasileira: pode-se dizer que não deixou nenhum de grande ou relativa importância, tendo sido antes um noticiarista inteligente, culto e bem informado (...)" (MARTINS, 1983, p. 469). Confundir seu papel de crítico com seu papel de romancista somente faria ofuscar a importância deste em prol daquele, além de mitigar as qualidades por vezes raras de sua obra romanesca, como no discutido Marta.

\section{Referências}

ALBUQUERQUE, Medeiros e. Minha vida: da infância à mocidade. 3 ed. Rio de Janeiro: Calvino Filho, 1933.

. Uma ordem bem obedecida. In: Quando eu era vivo...: memórias. 2 ed. Porto Alegre: Globo, 1945. p. $285-288$.

. Marta. 4 ed. São Paulo: Com-Arte; Edusp, 2013.

ASSIS, Machado de. Obra completa. Rio de Janeiro: Aguilar, 1959. v. I.

AZEVEDO, Aluísio. Ficção completa. Rio de Janeiro: Nova Aguilar, 2005. v. II.

BALZAC, Honoré. A Comédia Humana. Estudos de costume, cenas da vida provinciana. Trad. Gomes da Silveira. São Paulo: Editora Globo, 1950. v. V.

BOSI, Alfredo. História concisa da literatura brasileira. 46 ed. São Paulo: Cultrix, 2008. 
CANDIDO, Antonio. De cortiço a cortiço. Novos estudos CEBRAP, n. 30, jul. 1991, p. 111-129.

CARDOSO, Lúcio. Crônica da casa assassinada. Rio de Janeiro: Record, 1979.

DELEUZE, Gilles; GUATTARI, Félix. Mille plateaux: capitalisme et schizophrénie II. Paris: Minuit, 1980.

L'̂lle deserte et autres textes. Paris: Editions de Minuit, 2002.

O Anti-Édipo: Capitalismo e Esquizofrenia I.

Trad. Luiz B. L. Orlandi. São Paulo: Editora 34, 2011.

Kafka: por uma literatura menor. Trad. Cíntia Vieira da Silva. São Paulo: Autêntica, 2014.

DOYLE, Plínio. Biblioteca. In: Uma vida. 2 ed.

Rio de Janeiro: Casa da Palavra; Fundação Casa de Rui Barbosa, 1999. p. 59-104.

FOUCAULT, Michel. História da loucura na Idade Clássica. Trad. José Teixeira Coelho Netto. São Paulo: Perspectiva, 1978.

MARCUSE, Herbert. Eros e Civilização. Trad. Álvaro Cabral. São Paulo: Círculo do Livro, 1982.

MARTINS, Wilson. História da inteligência brasileira: (1915-1933). v. IV. São Paulo: Cultrix; Edusp, 1978.

. A crítica literária no Brasil: (1724-1939). v. I. Rio de Janeiro: Francisco Alves, 1983.

A crítica modernista. In: COUTINHO, Afrânio (Dir.). A literatura no Brasil. 5 ed. São Paulo: Global, 1999. v. 5. p. 591-634.

MOISÉS, Massaud. Introdução e evolução do Simbolismo no Brasil. In: O simbolismo. 3 ed. São Paulo: Cultrix, 1969. p. 48-67.

NASSAR, Raduan. Lavoura arcaica. 3 ed. São Paulo: Companhia das Letras, 2009.

NETO, Coelho. Obra seleta. v. I. Rio de Janeiro: Aguilar, 1958.

NIETZSCHE, Friedrich. Genealogia da moral. Trad. Paulo César de Souza. São Paulo: Cia. das Letras, 1999.

REICH, Wihelm. A Revolução Sexual. Trad. Ary Blaustein. Rio de Janeiro: Zahar, 1976.

SALVADOR, Vitor Celso. A "crônica literária” de Medeiros e Albuquerque: resenhas e notícias literárias publicadas no vespertino A Notícia de 1897 a 1908. Assis: UNESP, 2012. Dissertação de Mestrado.

O impressionismo crítico de Medeiros e Albuquerque (1867-1934) no estudo de romances brasileiros (1897-1908). Disponível em: http:// www.assis.unesp.br/Home/PosGraduacao/Letras/ ColoquioLetras/vitorcelso.pdf Acesso em 19 mai. 2015.
SIBERTIN-BLANC, Guillaume. Deleuze et l'Anti-Oedipe: la production du désir. Paris: PUF, 2010.

TEIXEIRA, Ivan. Projeções da arte decadente no Brasil. In: ALBUQUERQUE, Medeiros e. Marta. 4 ed. São Paulo: Com-arte; Edusp, 2013. p. 7-17.

Recebido em: 01/06/2015 Aceito em: 17/09/2015 
